\title{
Differences in Cell Number Facilitate Fruit Size Variation in Rabbiteye Blueberry Genotypes
}

\author{
Lisa Klima Johnson and Anish Malladi ${ }^{1}$ \\ Department of Horticulture, 1111 Miller Plant Sciences, University of Georgia, Athens, GA 30602 \\ D. Scott NeSmith \\ Department of Horticulture, University of Georgia, GA Station, Griffin, GA 30223
}

\begin{abstract}
AdDitional Index words. cell division, cell expansion, fruit development, fruit growth, fruit weight
Abstract. Fruit size is a valuable commercial trait in blueberry. The cellular basis of variation in fruit size among rabbiteye blueberry (Vaccinium ashei) genotypes was investigated. Twenty genotypes, including cultivars and advanced selections from the University of Georgia blueberry breeding program, were analyzed. Among the 20 genotypes, fruit weight and fruit diameter varied by over threefold and 1.6-fold, respectively. Regression analysis indicated a linear relationship between fruit weight and fruit diameter $\left(R^{2}=0.97, P<0.001\right)$, suggesting that fruit diameter is a good predictor of fruit weight. Among the 20 genotypes, mesocarp cell number and cell area varied by almost 2.5-fold and 1.5-fold, respectively. Although fruit diameter and cell number were significantly related $\left(R^{2}=\right.$ $0.79, P<0.001)$, no relationship could be established between fruit diameter and cell area. These data indicate that variation in fruit size among rabbiteye blueberry genotypes is primarily facilitated by variation in cell number. Two small and two large fruit size genotypes were further analyzed. Differences in cell number among some of these genotypes were apparent at bloom suggesting that cell production before bloom is an important mechanism contributing to variation in final cell number. Differences in final cell number among other genotypes were manifested during fruit development, indicating that cell production during fruit development was also instrumental in determining variation in final cell number. This study suggests that fruit size variation in rabbiteye blueberry genotypes is determined by mechanisms that regulate cell production before bloom and during fruit development.
\end{abstract}

Fruit size is a commercially valuable trait in many horticultural crops, including rabbiteye blueberry. Sensory evaluations indicate a greater preference among consumers for large-sized blueberry fruit (Donahue et al., 2000; Saftner et al., 2008). Large fruit size is an important trait for selection during the development of new varieties in blueberry breeding programs (NeSmith, 2009). Although considerable variation in fruit size is observed among rabbiteye blueberry genotypes, the basis of this variation is not well understood. Understanding the cellular and molecular basis of such variation is essential to develop tools for enhancing fruit size either through breeding or through the manipulation of fruit growth using horticultural practices. In rabbiteye blueberry, the fleshy mesocarp constitutes the majority of the mature fruit (Edwards et al., 1970). Because growth of the mesocarp tissue is likely mediated by coordinated progression of cell production and cell expansion, these processes may be key factors determining fruit size. Dissecting the relative contribution of these factors is essential to develop a clear understanding of fruit size regulation.

Variation in fruit size is often associated with differences in cell number. Higher cell number is associated with larger fruit size in peach [Prunus persica (Scorza et al., 1991)], olive [Olea europaea (Rapoport et al., 2004)], strawberry [Fragaria xananassa (Cheng and Breen, 1992)], melon [Cucumis melo (Higashi et al., 1999)], apple [Malus Xdomestica (Denne, 1960)], sweet cherry [Prunus avium (Olmstead et al., 2007)], and tomato [Solanum lycopersicum (Bertin et al., 2003, 2009; Bohner and Bangerth, 1988; Tanksley, 2004)]. Final cell number in the fruit may be determined by: 1) cell production within the ovary before bloom; and/or 2) the rate and duration

Received for publication 23 Aug. 2010. Accepted for publication 24 Oct. 2010. ${ }^{1}$ Corresponding author. E-mail: malladi@uga.edu. of cell production during fruit growth. In many fruit crops, cell production before bloom and immediately after pollination/ fertilization is the primary factor driving early fruit growth (Gillaspy et al., 1993). In peach and strawberry, cell number in the ovary or receptacle at bloom is an important factor determining final cell number (Cheng and Breen, 1992; Scorza et al., 1991). In fruits such as tomato, japanese pear (Pyrus pyrifolia), sweet cherry, and apple, multiple rounds of cell production during early fruit development regulate the final cell number (Bertin et al., 2009; Goffinet et al., 1995; Olmstead et al., 2007; Zhang et al., 2006). In rabbiteye blueberry, cell production occurs before bloom and during the initial stages of fruit growth (Cano-Medrano and Darnell, 1997; Darnell et al., 1992; Edwards et al., 1970). However, the effect of differences in cell production on variation in final cell number and fruit size among rabbiteye blueberry genotypes has not been determined.

Cell expansion is an important facilitator of organ growth. A majority of fruit growth, especially during the later stages of fruit development, is often achieved through cell expansion (Gillaspy et al., 1993). However, the contribution of cell expansion and final cell size to fruit size variation among genotypes is not clear. In tomato, fruit size and pericarp thickness were correlated with cell size among 20 genotypes (Cheniclet et al., 2005). In apple, cell size contributed to fruit size variation among five genotypes (Harada et al., 2005). Also, alteration in fruit size in a spontaneous apple mutant was associated with enhanced cell expansion (Malladi and Hirst, 2010). In peach, strawberry, japanese pear, and sweet cherry, differences in fruit size among large and small fruit size genotypes were not associated with differences in cell size (Cheng and Breen, 1992; Olmstead et al., 2007; Scorza et al., 1991; Zhang et al., 2006). Additionally, no relationship between fruit weight and cell size was observed among isogenic tomato lines differing in fruit 
size (Bertin et al., 2009). In rabbiteye blueberry, differences in fruit size between pollinated and parthenocarpic fruit were associated with differences in cell size (Cano-Medrano and Darnell, 1997). However, the relationship between fruit size and cell size among rabbiteye blueberry genotypes has not been determined.

The primary goal of this study was to determine the relationships among fruit size, cell number, and cell area across rabbiteye blueberry genotypes. In addition, the relationships among these parameters in the ovary at bloom and in mature fruit were investigated.

\section{Materials and Methods}

Plant material. All plants used in this study were grown at the Georgia Station in Griffin, GA. Plants were grown in pine bark mulch, fertilized using standard blueberry cultivation practices, and were irrigated two to four times per week as needed. The presence of supplemental bees and numerous additional blueberry plots at the Georgia Station provided excellent conditions for pollination.

In 2008, 20 rabbiteye blueberry genotypes (cultivars and advanced selections from the University of Georgia blueberry breeding program) were chosen for analysis of the relationships among fruit weight, fruit diameter, cell number, and cell area. Fifty mature berries from five plants were randomly collected from each of the previously mentioned 20 genotypes. Fruit weight and diameter across the widest part of the fruit were measured. Eight fruit from each genotype were randomly selected from the 50-fruit sample for microscopy analysis. For microscopy, fruit were fixed in FAA (50\% ethyl alcohol, $10 \%$ formalin, $5 \%$ acetic acid) and stored at room temperature until further analysis.

In 2009, four genotypes were chosen to study specific relationships among fruit size, cell number, and cell area in the ovary at bloom and in mature fruit. The genotypes chosen for this study were 'Powderblue', 'Brightwell', T-959, and T-960. Four single plant replicates of each genotype, established in 2006, were used in this study. Fruit size measurement and sample collection for microscopy were performed for each of these genotypes at their respective phenological stages of bloom and maturity. Bloom corresponded to the stage when greater than $50 \%$ of the flowers on the plant were completely open. Maturity corresponded to the stage when greater than $50 \%$ of fruit on the plant were fully ripe (blue to black in color). Ovary diameter at bloom and fruit diameter at maturity were measured on 10 flowers/fruit per replicate. For microscopy studies, three flowers/fruit were randomly collected from each replicate at bloom and at maturity, fixed in FAA, and stored at room temperature until further analysis.

Microscopy. For the 2008 study, fruit from each genotype were removed from the FAA solution and rinsed thoroughly in deionized water. For determining the fruit, locule, and mesocarp cross-sectional areas, berries were cut at the widest part of the fruit and imaged using a light microscope (Stereomaster digital zoom high-resolution microscope; Fisher Scientific, Pittsburgh, PA) with imaging software (Micron; Westover Scientific, Bothell, WA). Half of the fruit was mounted onto a block and sectioned using a vibratome (Micro-Cut H 1200; Bio-Rad, Hercules, CA) at the widest part of the fruit. In the 2009 study, mature fruit were sectioned as described previously. Ovary samples collected at bloom were removed from
FAA, rinsed in water, and embedded in 6\% agarose before sectioning (Ruzin, 1999). Sections from mature fruit ranged from 90 to $120 \mu \mathrm{m}$ in thickness, whereas those at bloom ranged from 15 to $30 \mu \mathrm{m}$. All sections were rehydrated and stained using aqueous toluidine blue. Images of the sections were captured with a light microscope (BX51; Olympus, Center Valley, PA) fitted with a digital camera (DP70; Olympus).

IMAGE ANALYSIS AND MEASUREMENT OF CELL NUMBER AND CELL AREA. Fruit diameter, locule area, and mesocarp area were determined using images of the cut surface of the fruit with the aid of ImageJ software (National Institutes of Health, Bethesda, MD). Areas of the epidermis and the locules were excluded from the total fruit cross-section area to determine the mesocarp area. Images of sectioned fruit were printed for determining cell number and cell area. The mesocarp region was divided into three zones: outer mesocarp, middle mesocarp, and inner mesocarp (according to Cano-Medrano and Darnell, 1997). A grid of known area was placed over each of the three zones and cells that were at least $50 \%$ within the grid were counted. The grid area was divided by the number of cells within it to determine cell area. The average cell area is presented here. Cell number was determined by dividing the mesocarp area by the average cell area.

Statistical anAlyses. Statistical analyses and figure preparation were performed using Minitab 15 (Minitab, State College, PA) and SigmaPlot 11 (Systat Software, San Jose, CA). For the 2008 study, the cell number data were logtransformed before regression analysis of fruit diameter and cell number to ensure normality. Mean separation of ovary/fruit diameter, cell number, and cell area was performed using Tukey's multiple comparison test $(\alpha=0.05)$ after one-way analysis of variance.

\section{Results}

Fruit Size, CELl NUMBER, AND CELl AREA IN RABBiteye blUEBERRY GENOTYPES. Fruit weight varied over a threefold range among the 20 genotypes analyzed in 2008 (Table 1). Fruit from the advanced selections T-959 and T-877 had the highest and lowest fruit weight, respectively. Fruit diameter varied by over 1.6-fold among the 20 genotypes with T-959 and T-877 displaying the largest and the smallest fruit diameter, respectively. Many of the commercial cultivars such as Brightwell, Powderblue, Alapaha, and Premier were at the lower end of the fruit size range. Mesocarp cell area displayed a 1.5-fold variation. The largest cell area was observed in 'Vernon', whereas 'Brightwell' displayed the smallest cell area. Cell number within the mesocarp varied by almost 2.5 -fold among the 20 genotypes. The highest cell number was observed in T-959, the genotype with the largest fruit size, whereas the lowest cell number was observed in T-877, the genotype with the smallest fruit size. Most of the genotypes had fruit with five compound locules. However, 'Climax' and T-877 had $75 \%$ or greater fruit with six or more locules (data not shown).

RELATIONSHIPS AMONG FRUIT SIZE, CELL NUMBER, AND CELL AREA IN RABBITEYE BLUEBERRY GENOTYPES. A strong linear relationship between fruit weight and fruit diameter was observed among the 20 genotypes analyzed in $2008\left[R^{2}=0.97\right.$, $P<0.001$ (Fig. 1A)]. A large proportion of the variation in fruit size among the genotypes was associated with variation in cell number. Fruit diameter was positively associated with cell number $\left[R^{2}=0.79, P<0.001\right.$ (Fig. 1B)]. A similar relationship 
Table 1. Fruit weight, fruit diameter, cell area, and cell number in 20 rabbiteye blueberry genotypes (2008).

\begin{tabular}{|c|c|c|c|c|}
\hline Genotype & $\begin{array}{c}\text { Fruit wt } \\
{[\text { mean } \pm \mathrm{SE}(\mathrm{g})]^{\mathrm{z}}}\end{array}$ & $\begin{array}{c}\text { Fruit diam } \\
{[\mathrm{mean} \pm \mathrm{SE}(\mathrm{mm})]^{\mathrm{z}}}\end{array}$ & $\begin{array}{c}\text { Cell area } \\
{\left[\text { mean } \pm \mathrm{SE}\left(\times 10^{3} \mu \mathrm{m}^{2}\right)\right]^{\mathrm{y}}}\end{array}$ & $\begin{array}{c}\text { Cell no. } \\
{\left[\text { mean } \pm \mathrm{SE}\left(\times 10^{3}\right)\right]^{\mathrm{y}}}\end{array}$ \\
\hline $\mathrm{T}-877$ & $0.89 \pm 0.20$ & $11.58 \pm 0.90$ & $17.62 \pm 2.27$ & $5.68 \pm 1.32$ \\
\hline 'Brightwell' & $1.08 \pm 0.25$ & $12.61 \pm 0.97$ & $14.47 \pm 1.72$ & $7.83 \pm 1.62$ \\
\hline 'Alapaha' & $1.22 \pm 0.21$ & $12.76 \pm 0.84$ & $16.47 \pm 1.42$ & $7.51 \pm 1.79$ \\
\hline 'Premier' & $1.26 \pm 0.34$ & $13.28 \pm 1.20$ & $14.80 \pm 1.97$ & $7.22 \pm 1.37$ \\
\hline $\mathrm{T}-724$ & $1.34 \pm 0.24$ & $13.55 \pm 0.98$ & $15.67 \pm 1.28$ & $6.96 \pm 0.96$ \\
\hline $\mathrm{T}-728$ & $1.38 \pm 0.27$ & $13.32 \pm 0.97$ & $17.70 \pm 1.98$ & $7.13 \pm 1.02$ \\
\hline $\mathrm{T}-765$ & $1.55 \pm 0.25$ & $14.42 \pm 0.83$ & $15.02 \pm 1.65$ & $9.07 \pm 1.72$ \\
\hline $\mathrm{T}-670$ & $1.70 \pm 0.31$ & $14.93 \pm 0.89$ & $15.31 \pm 0.87$ & $9.52 \pm 1.44$ \\
\hline $\mathrm{T}-672$ & $1.73 \pm 0.39$ & $15.60 \pm 1.35$ & $15.42 \pm 2.19$ & $10.21 \pm 1.41$ \\
\hline $\mathrm{T}-754$ & $1.75 \pm 0.32$ & $15.64 \pm 0.97$ & $16.57 \pm 2.86$ & $10.16 \pm 1.59$ \\
\hline $\mathrm{T}-460$ & $1.75 \pm 0.66$ & $14.81 \pm 2.00$ & $16.47 \pm 3.94$ & $9.56 \pm 2.77$ \\
\hline $\mathrm{T}-960$ & $2.24 \pm 0.52$ & $17.23 \pm 1.50$ & $19.61 \pm 2.26$ & $9.66 \pm 1.28$ \\
\hline $\mathrm{T}-965$ & $2.81 \pm 0.86$ & $18.58 \pm 2.29$ & $18.12 \pm 2.33$ & $12.53 \pm 2.47$ \\
\hline T-959 & $2.82 \pm 0.67$ & $18.84 \pm 1.68$ & $16.76 \pm 2.88$ & $14.02 \pm 2.92$ \\
\hline
\end{tabular}

${ }^{\mathrm{z}}$ Fruit weight and diameter were measured on $\approx 50$ mature fruit from each genotype.

${ }^{\mathrm{y}} \mathrm{Cell}$ area and number in the mesocarp were measured in mature fruit $(\mathrm{n}=8)$.

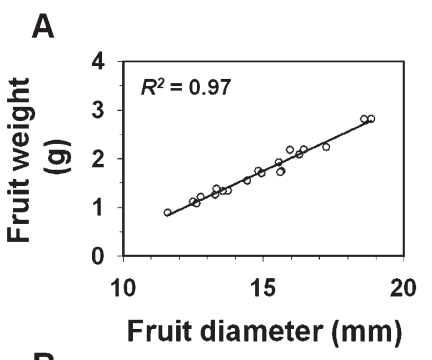

B

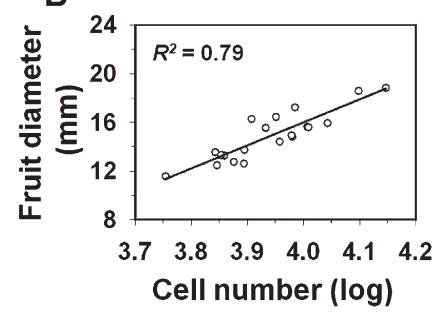

C

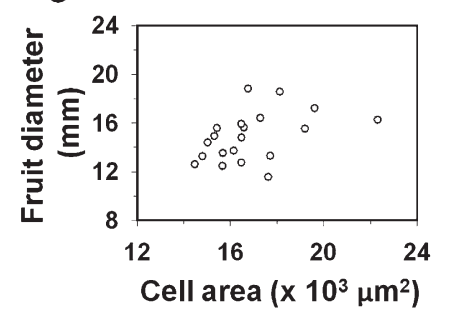

Fig. 1. Relationships among fruit weight, fruit diameter, cell number, and cell area across 20 rabbiteye blueberry genotypes (2008). (A) Fruit weight and fruit diameter displayed a linear relationship $(P<0.001, y=-2.263+0.268 x)$. (B) Variation in fruit diameter was primarily associated with variation in cell number $(P<0.001, y=-59.587+18.896 x)$. Data for cell number were $\log$ transformed to ensure normality. (C) No significant relationship was found between fruit diameter and cell area. was also observed between fruit weight and cell number $\left[R^{2}=\right.$ $0.77, P<0.001$ (data not shown)]. No significant relationship between fruit diameter and final cell area was found in this study $\left[R^{2}=0.18, P=0.061\right.$ (Fig. 1C)]. However, a weak relationship between fruit weight and cell area was observed among the 20 genotypes $\left[R^{2}=0.20, P=0.049\right.$ (data not shown)].

Fruit size, Cell Number, AND CELl AREA AT BLOOM AND MATURITY. Four genotypes representing two of the smaller ('Powderblue' and 'Brightwell') and two of the larger (T-959 and T-960) fruit size genotypes from the 2008 study were further analyzed in 2009. 'Brightwell' exhibited the lowest ovary diameter at bloom, whereas the other three genotypes did not differ significantly (Fig. 2A). At maturity, no significant differences in fruit size were observed between 'Brightwell' and 'Powderblue' and between T-959 and T-960. However, 'Brightwell' and 'Powderblue' had significantly smaller fruit diameter than T-959 and T-960 (Fig. 2A). Between bloom and maturity, fruit diameter increased by 4 - and 4.65 -fold in 'Powderblue' and 'Brightwell', respectively. During fruit development, fruit diameter in the large fruit size genotypes, T-959 and T-960, increased by 5.39- and 4.93-fold, respectively.

At bloom, the lowest and highest cell numbers were observed in 'Brightwell' and T-959, respectively (Fig. 2B). Cell number at bloom in T-959 was 1.6-fold higher than that in 'Brightwell'. Interestingly, cell number at bloom in the large fruit size genotype, T-960, was similar to that in 'Brightwell' and 1.36-fold lower than that in T-959. Cell number at bloom in the small fruit size cultivar, Powderblue, was not significantly different from that in T-959 and T-960, but was 1.48 -fold higher than that in 'Brightwell' (Fig. 2B). At maturity, cell number in T-959 was 2.17-, 1.82-, and 1.29-fold higher than that in 'Powderblue', 'Brightwell', and T-960, respectively (Fig. 2B). Also, cell number at maturity in T-960 was 1.68 -fold 
A

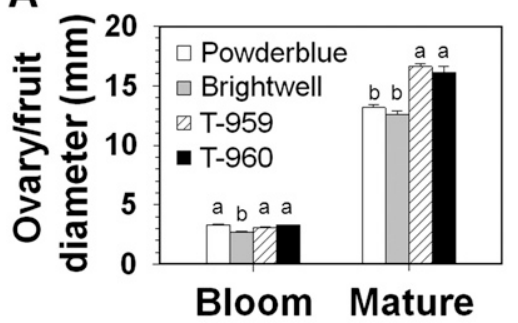

B

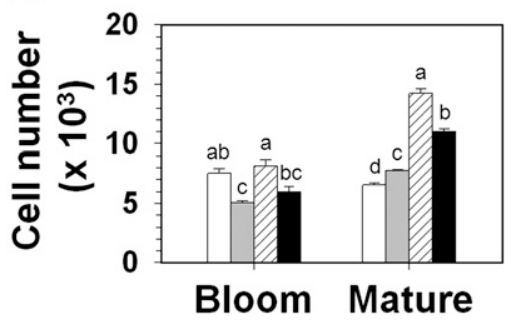

C

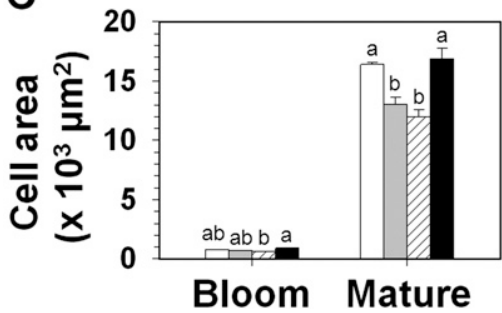

Fig. 2. Ovary/fruit diameter (A), cell number (B), and cell area (C) at bloom and in mature fruit in four rabbiteye blueberry genotypes (2009). Error bars indicate the SE of the means $(n=4)$. Different letters above the bars indicate significant difference among genotypes within each stage (Tukey's mean separation test at $P<0.05)$.

and 1.41-fold higher than that in 'Powderblue' and 'Brightwell', respectively. The increase in cell number between bloom and maturity ranged from 1.53-fold in 'Brightwell' to 1.85-fold in T-960. Cell number was not significantly different between bloom and maturity in 'Powderblue'.

At bloom, cell area in the ovary was similar in 'Powderblue', 'Brightwell', and T-960 (Fig. 2C). T-959 fruit had the lowest cell area at bloom, which was significantly different from that in T-960. At maturity, cell area was not different between 'Powderblue' and T-960 and between 'Brightwell' and T-959 (Fig. 2C). 'Brightwell' and T-959 had significantly lower cell area $(20 \%$ to $29 \%)$ than that of the other genotypes. All four genotypes showed a large increase in cell area during the period of fruit growth and development. Cell area in 'Powderblue' increased by over 21 -fold during fruit development, whereas it increased by over 18 -fold in the other three genotypes.

RELATIONSHIPS AMONG FRUIT SIZE, CELL NUMBER, AND CELL AREA AT BLOOM AND MATURITY. Among the four genotypes analyzed in 2009, final fruit diameter was not dependent on the ovary diameter at bloom $\left(R^{2}=0.11, P=0.21\right)$, suggesting that ovary size is not a good indicator of final fruit size in rabbiteye blueberry (Fig. 3A). Final cell number was not significantly associated with cell number in the ovary at bloom among the four genotypes (Fig. 3B). Interestingly, a significant relationship was observed between cell area in the ovary at bloom and final cell area $\left[R^{2}=0.52, P=0.001\right.$ (data not shown)]. Confirming results from the study across the 20 genotypes,
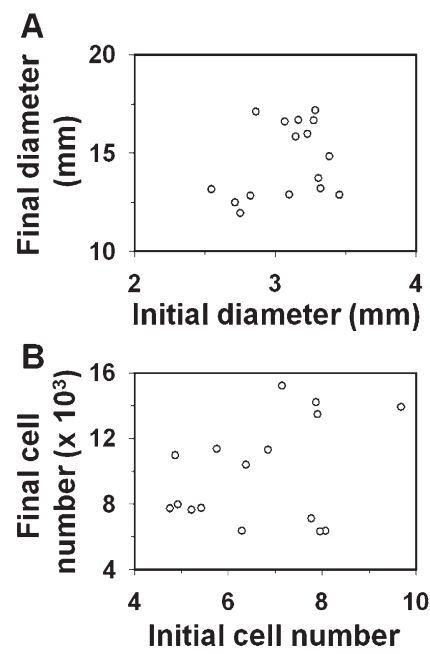

$\left(\times 10^{3}\right)$

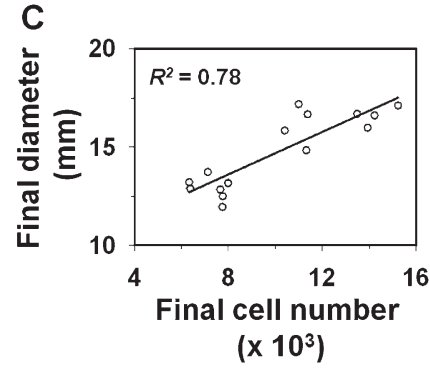

Fig. 3. Relationships among ovary diameter, fruit diameter, and cell number at bloom (Initial) and at maturity (Final) in 'Powderblue', 'Brightwell', T-959, and T-960 (2009). (A) No significant relationship was found between the initial ovary diameter and the final fruit diameter. (B) No significant relationship was observed between the initial cell number in the ovary at bloom and the final cell number in mature fruit. (C) Variation in final fruit diameter among the four genotypes was primarily associated with variation in final cell number $(P<0.001, y=9.285+0.00054 x)$.

variation in final fruit diameter was primarily related to variation in final cell number among the four genotypes analyzed in $2009\left[R^{2}=0.78, P<0.001\right.$ (Fig. 3C) $]$. No significant relationship was found between final fruit diameter and final cell area among the four genotypes (data not shown).

\section{Discussion}

Fruit size variation in rabbiteye blueberry was primarily determined by variation in cell number within the mesocarp in both years of this study, indicating that cell number is a key factor determining fruit size in rabbiteye blueberry. A similar relationship between fruit size and cell number has been observed across multiple fruit crops such as peach, tomato, olive, apple, japanese pear, and sweet cherry (Bertin et al., 2003; Harada et al., 2005; Olmstead et al., 2007; Rapoport et al., 2004; Scorza et al., 1991; Zhang et al., 2006). Hence, mechanisms that regulate cell production, thereby determining final cell number, may be key components of fruit size regulation. In fact, analysis of quantitative trait loci (QTLs) affecting fruit size in tomato indicated that a majority of such QTLs were associated with cell production-related processes (Bertin et al., 2009). FW2.2, a gene determining fruit size in tomato, regulates fruit size through its influence on cell production, particularly during early fruit development (Cong et al., 
2002; Frary et al., 2000). In apple, expression of many cell division cycle-related genes was associated with cell production and growth during fruit development (Malladi and Johnson, 2011). Similarly, genes regulating cell production may be important regulators of fruit size in rabbiteye blueberry. Hence, analyses of genetic and molecular components involved in regulating cell production may lead to the identification of fruit size determinants in rabbiteye blueberry.

Data from this study indicate that mechanisms regulating cell production before bloom as well as during the period of fruit development determine differences in final cell number among rabbiteye blueberry genotypes. A majority of cell production appears to occur before bloom in rabbiteye blueberry (Fig. 2; Cano-Medrano and Darnell, 1997). Differences in cell number between T-959 and 'Brightwell' and between T-959 and T-960 were apparent at bloom, indicating that cell production before bloom is an important factor determining variation in cell number across genotypes. Similarly, in peach and strawberry fruit, cell number at anthesis is a key determinant of final cell number and fruit size (Cheng and Breen, 1992; Scorza et al., 1991). However, among the four rabbiteye blueberry genotypes analyzed in the 2009 study, there was no significant relationship between cell number at bloom and cell number at maturity, indicating that additional mechanisms determine differences in final cell number. Differences in cell number between 'Powderblue' and T-959, 'Powderblue' and T-960, and between 'Brightwell' and T-960 were manifested during fruit development. These data indicate that the magnitude of cell production during fruit growth is another potential mechanism determining differences in final cell number across genotypes. Cell production during early fruit growth regulates final cell number in other fruits such as apple, japanese pear, sweet cherry, and tomato (Bertin et al., 2009; Goffinet et al., 1995; Olmstead et al., 2007; Zhang et al., 2006). Whether differences in cell number among rabbiteye blueberry genotypes are facilitated by differences in the rate or the duration of cell production remains to be determined.

Cell area increased by 18 - to 21 -fold during fruit development indicating that cell expansion is a key facilitator of fruit growth in rabbiteye blueberry. However, no significant relationship was observed between cell area and fruit diameter, whereas only a weak relationship was identified between cell area and fruit weight. Hence, genetic differences in fruit size among rabbiteye blueberry genotypes may not be mediated by processes that regulate cell expansion. A previous study in rabbiteye blueberry indicated that altered fruit size resulting from lack of pollination, or in response to gibberellin (GA) treatment, was associated with changes in cell size (CanoMedrano and Darnell, 1997). It is likely that environmental factors or GA treatment primarily alter rabbiteye blueberry fruit size through their effects on cell size, whereas genetic differences in fruit size are determined by differences in cell number.

A major increase in fruit size is associated with increase in locule number in tomato, a berry similar to blueberry (Barrero and Tanksley, 2004; Cong et al., 2008). In the current study, little variation in locule number was observed among the 20 genotypes (data not shown). In fact, some of the small to medium fruit size genotypes, T-877 and 'Climax', displayed higher locule number. These data suggest that variation in locule number may not be a major factor regulating fruit size in rabbiteye blueberry.
In this study, the relationships among fruit size and cellular parameters such as cell number and cell area were analyzed in rabbiteye blueberry genotypes. Cell number was found to be the primary factor determining fruit size variation. Data from this study also suggest that mechanisms that regulate cell production before bloom and during fruit development are important in determining variation in final cell number across genotypes. Future work should be focused on elucidating such mechanisms through genetic and/or molecular approaches to enhance our understanding of the regulation of fruit size and to develop tools for optimizing fruit size in rabbiteye blueberry production.

\section{Literature Cited}

Barrero, L.S. and S.D. Tanksley. 2004. Evaluating the genetic basis of multiple-locule fruit in a broad cross section of tomato cultivars. Theor. Appl. Genet. 109:669-679.

Bertin, N., C. Borel, B. Brunel, C. Cheniclet, and M. Causse. 2003. Do genetic make-up and growth manipulation affect tomato fruit size by cell number, or cell size and DNA endoreduplication? Ann. Bot. (Lond.) 92:415-424.

Bertin, N., M. Causse, B. Brunel, D. Tricon, and M. Genard. 2009. Identification of growth processes involved in QTLs for tomato fruit size and composition. J. Expt. Bot. 60:237-248.

Bohner, J. and F. Bangerth. 1988. Effects of fruit-set sequence and defoliation on cell number, cell-size and hormone levels of tomato fruits (Lycopersicon esculentum Mill) within a truss. Plant Growth Regulat. 7:141-155.

Cano-Medrano, R. and R.L. Darnell. 1997. Cell number and cell size in parthenocarpic vs. pollinated blueberry (Vaccinium ashei) fruits. Ann. Bot. (Lond.) 80:419-425.

Cheng, G.W. and P.J. Breen. 1992. Cell count and size in relation to fruit size among strawberry cultivars. J. Amer. Soc. Hort. Sci. 117: 946-950.

Cheniclet, C., W.Y. Rong, M. Causse, N. Frange, L. Bolling, J.-P. Carde, and J.-P. Renaudin. 2005. Cell expansion and endoreduplication show a large genetic variability and contribute strongly to tomato fruit growth. Plant Physiol. 139:1984-1994.

Cong, B., L.S. Barrero, and S.D. Tanksley. 2008. Regulatory change in YABBY-like transcription factor led to evolution of extreme fruit size during tomato domestication. Nat. Genet. 40:800-804.

Cong, B., J.P. Liu, and S.D. Tanksley. 2002. Natural alleles at a tomato fruit size quantitative trait locus differ by heterochronic regulatory mutations. Proc. Natl. Acad. Sci. USA 99:13606-13611.

Darnell, R.L., G.W. Stutte, G.C. Martin, J.D. Early, and G.A. Lang. 1992. Developmental physiology of rabbiteye blueberry. Hort. Rev. (Amer. Soc. Hort. Sci.) 13:339-405.

Denne, P. 1960. The growth of apple fruitlet and the effect of early thinning on fruit development. Ann. Bot. (Lond.) 24:397-406.

Donahue, D.W., P.W. Penoit, B.J. Lagasse, and W.R. Buss. 2000. Consumer and instrumental evaluation of Maine wild blueberries for the fresh pack market. Postharvest Biol. Technol. 19:221-228.

Edwards, T.W., W.B. Sherman, and R.H. Sharpe. 1970. Fruit development in short and long cycle blueberries. HortScience 5:274275.

Frary, A., T.C. Nesbitt, S. Grandillo, E. van der Knaap, B. Cong, J.P. Liu, J. Meller, R. Elber, K.B. Alpert, and S.D. Tanksley. 2000. fw2.2: A quantitative trait locus key to the evolution of tomato fruit size. Science 289:85-88.

Gillaspy, G., H. Ben-David, and W. Gruissem. 1993. Fruits: A developmental perspective. Plant Cell 5:1439-1451.

Goffinet, M.C., T.L. Robinson, and A.N. Lakso. 1995. A comparison of empire apple fruit size and anatomy in unthinned and hand-thinned trees. J. Hort. Sci. 70:375-387.

Harada, T., W. Kurahashi, M. Yanai, Y. Wakasa, and T. Satoh. 2005. Involvement of cell proliferation and cell enlargement in increasing the fruit size of Malus species. Sci. Hort. 105:447-456. 
Higashi, K., K. Hosoya, and H. Ezura. 1999. Histological analysis of fruit development between two melon (Cucumis melo L. reticulatus) genotypes setting a different size of fruit. J. Expt. Bot. 50:1593-1597. Malladi, A. and P.M. Hirst. 2010. Increase in fruit size of a spontaneous mutant of 'Gala' apple (Malus $\times$ domestica Borkh.) is facilitated by altered cell production and enhanced cell size. J. Expt. Bot. 61:30033013.

Malladi, A. and L.K. Johnson. 2011. Expression profiling of cell cycle genes reveals key facilitators of cell production during carpel development, fruit set, and fruit growth in apple (Malus $\times$ domestica Borkh.). J. Expt. Bot. 62:205-219.

NeSmith, D.S. 2009. Blueberry cultivar development at the University of Georgia. Acta Hort. 810:79-86.

Olmstead, J.W., A.F. Lezzoni, and M.D. Whiting. 2007. Genotypic differences in sweet cherry fruit size are primarily a function of cell number. J. Amer. Soc. Hort. Sci. 132:697-703.
Rapoport, H.F., T. Manrique, and R. Gucci. 2004. Cell division and expansion in the olive fruit. Acta Hort. 636:461-465.

Ruzin, S.E. 1999. Plant microtechnique and microscopy. Oxford University Press, New York, NY.

Saftner, R., J. Polashock, M. Ehlenfeldt, and B. Vinyard. 2008. Instrumental and sensory quality characteristics of blueberry fruit from twelve cultivars. Postharvest Biol. Technol. 49:19-26.

Scorza, R., L.G. May, B. Purnell, and B. Upchurch. 1991. Differences in number and area of mescocarp cells between small- and largefruited peach cultivars. J. Amer. Soc. Hort. Sci. 116:861-864.

Tanksley, S.D. 2004. The genetic, developmental, and molecular bases of fruit size and shape variation in tomato. Plant Cell 16:S181-S189.

Zhang, C.X., K. Tanabe, S.P. Wang, F. Tamura, A. Yoshida, and K. Matsumoto. 2006. The impact of cell division and cell enlargement on the evolution of fruit size in Pyrus pyrifolia. Ann. Bot. (Lond.) 98: $537-543$. 